\title{
Seasonal availability of abundant, energy-rich prey influences the abundance and diet of a marine predator, the Steller sea lion Eumetopias jubatus
}

\author{
Jamie N. Womble ${ }^{1,2, *}$, Michael F. Sigler ${ }^{2}$ \\ ${ }^{1}$ School of Fisheries and Ocean Sciences, University of Alaska Fairbanks, 11120 Glacier Highway, Juneau, Alaska 99801, USA \\ ${ }^{2}$ National Marine Fisheries Service, NOAA, Alaska Fisheries Science Center, Auke Bay Laboratory, 11305 Glacier Highway, \\ Juneau, Alaska 99801-8626, USA
}

\begin{abstract}
Steller sea lions Eumetopias jubatus are central-place foragers that forage in the marine environment while using terrestrial sites to rest and care for young. Some terrestrial sites are used seasonally; however, the reasons for doing so are not fully understood. We addressed the hypothesis that seasonal availability of prey influences seasonal abundance and diet of sea lions. We quantified monthly prey availability and sea lion abundance and quarterly diet composition at Benjamin Island in SE Alaska (2001-2004). Large numbers of sea lions occupied Benjamin Island during the nonbreeding season from October to April when Pacific herring Clupea pallasii biomass was highest. Herring was the most common species in sea lion diet (frequency of occurrence [FO] $=90 \%$ ) and comprised over $81 \%$ of the available pelagic prey biomass and $96 \%$ of the energy encountered during pelagic surveys. Walleye pollock Theragra chalcogramma accounted for $19 \%$ of the available prey biomass but was only slightly less common in sea lion diet $(\mathrm{FO}=88 \%)$ than herring. Herring biomass was correlated with the number of sea lions; in contrast, there was no relationship between pollock biomass and number of sea lions. Several fish species were found in nearshore areas, but were uncommon in sea lion diet. Sea lions consumed the available pelagic prey but little of the available nearshore prey. The FO of herring and pollock in sea lion diet did not differ significantly between seasons; however, the FO of other seasonal prey species differed between seasons. Seasonal occupation of Benjamin Island by sea lions is influenced by seasonally available, densely aggregated, energy-rich prey.
\end{abstract}

KEY WORDS: Seasonal $\cdot$ Prey availability $\cdot$ Abundance $\cdot$ Diet $\cdot$ Energy $\cdot$ Eumetopias jubatus $\cdot$ Clupea pallasii · Theragra chalcogramma

Resale or republication not permitted without written consent of the publisher

\section{INTRODUCTION}

The ideal free distribution predicts that the distribution of organisms among foraging sites should match the distribution of resources. Spatial and temporal changes in resource availability can influence prey density (Fretwell 1972), which in turn influences predator density (Carbone \& Gittleman 2002). In the marine environment, changes in resource availability can influence all trophic levels, ranging from plankton to top marine predators (Croxall 1992). For upper- trophic level marine predators that exhibit a centralplace foraging strategy, such as pinnipeds or seabirds (Orians \& Pearson 1977), the availability of resources around a colony can influence their distribution, abundance, survival, and foraging behavior (e.g. Boyd et al. 1998, Soto et al. 2004).

The Steller sea lion Eumetopias jubatus is an otariid found throughout the North Pacific Rim that relies on the marine environment to meet its energetic and nutritional demands while using terrestrial sites to rest, breed, care for young, and avoid predators, hence 
exhibiting a central-place foraging strategy (Orians \& Pearson 1977). In contrast to capital breeders, which depend upon stored body reserves to nourish offspring (Jönsson 1997), adult female Steller sea lions rely upon intermittent foraging trips during an extended lactation period (10 mo to $>3 \mathrm{yr}$ ) to deliver energy to their dependent young (Pitcher \& Calkins 1981).

In SE Alaska, during the breeding season from midMay through late July (Pitcher et al. 2001), sea lions typically make seasonal migrations to rookeries, which are located along the outer coast. After the breeding season, females with dependent young depart rookeries and migrate to terrestrial haulout sites (Calkins \& Pitcher 1982). The availability of seasonally predictable prey resources near a terrestrial haulout site may be critical in order to decrease energy spent traveling to foraging sites and increase energy allocated to the female and ultimately delivered to offspring during the extended lactation period.

Several seasonally available prey species are abundant and densely aggregated during the non-breeding season of Steller sea lions and can be seasonally important to the foraging ecology and reproductive success of Steller sea lions. In SE Alaska, sea lions are seasonally associated with spring-spawning aggregations of eulachon Thaleichthys pacificus (Marston et al. 2002, Sigler et al. 2004) and herring Clupea pallasii (Womble et al. 2005), and in Prince William Sound, sea lions are associated with overwintering herring schools (Thomas \& Thorne 2001).

Prey consumption patterns of Steller sea lions in the western stock suggest that sea lions forage on seasonally abundant and densely aggregated prey (Sinclair \& Zeppelin 2002); however, the influence of seasonal prey availability on sea lion diet and abundance has yet to be quantified. Thus, our objectives were to assess the seasonal abundance and diet of Steller sea lions in relation to seasonal prey availability. Specifically, we predicted that sea lion abundance and diet would vary depending on seasonally available prey biomass and associated energy density around a terrestrial haulout site during the non-breeding season of Steller sea lions. We examined the hypothesis that the seasonal availability of prey influences the seasonal abundance and seasonal diet of Steller sea lions at Benjamin Island, SE Alaska. We tested the following predictions: (1) the number of sea lions at Benjamin Island is correlated with the biomass of herring; (2) the number of sea lions at Benjamin Island is correlated with the biomass of walleye pollock Theragra chalcogramma; (3) the frequency of occurrence of prey species in sea lion diet reflects changes in seasonal availability of pelagic and nearshore prey; and (4) diet diversity increases in spring when forage fish are spawning.

\section{MATERIALS AND METHODS}

Sea lion seasonal abundance at Benjamin Island and along transects. Aerial surveys were used to count the number of sea lions at Benjamin Island, SE Alaska $\left(58^{\circ} 33.7^{\prime} \mathrm{N}, 134^{\circ} 54.8^{\prime} \mathrm{W}\right.$ ) (Fig. 1) from March 2001 to May 2004. Surveys were conducted monthly from a floatplane (Cessna 206) between 09:00 and 14:00 h and, when possible, within $3 \mathrm{~h}$ of low tide. The observer-photographer sat in the front seat and photographed sea lions on shore through an open window from an altitude of 250 to $300 \mathrm{~m}$ and at a speed of 183 to $210 \mathrm{~km} \mathrm{~h}^{-1}$.

Photographic images of haulouts were taken using a $35 \mathrm{~mm}$ autofocus camera (Nikon 8008S) with a motor drive equipped with a 70-210 $\mathrm{mm}$ zoom lens and a $35 \mathrm{~mm}$ autofocus digital camera (Nikon D1X) equipped with a 70-300 $\mathrm{mm}$ zoom lens. Overlapping images were taken if more than 1 image was needed to cover the entire site. The clearest image was projected and each sea lion in the image was counted. Each image was counted twice by an experienced counter.

In addition to counting the number of sea lions ashore at Benjamin Island, we also enumerated sea lions along acoustic transects which were conducted monthly. An observer stationed on the bridge of the $11 \mathrm{~m}$ commercial fishing vessel FV 'Williwaw' used Nikon $7 \times 50$ binoculars to scan for sea lions in the water along the transect route (Fig. 1). All surveys occurred during daylight hours to facilitate sea lion observations.

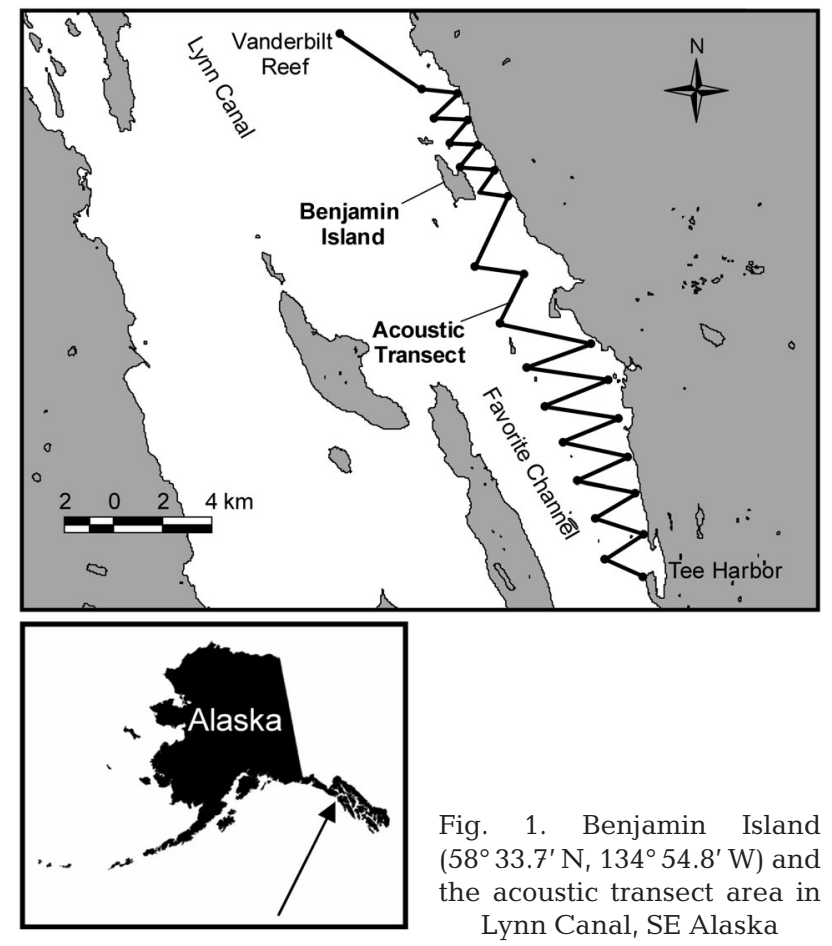


Sea lion diet. Steller sea lion scat samples (total $\mathrm{n}=$ 787) were collected during 2001 ( $\mathrm{n}=252), 2002$ ( $\mathrm{n}=$ 213), 2003 ( $\mathrm{n}=213)$, and $2004(\mathrm{n}=109)$. Samples were collected during February, April, October, and December each year to determine the seasonal changes in sea lion diet. During 2004, samples were only collected in February and April. Samples were not collected during the breeding season, as Benjamin Island is not typically used by sea lions at that time.

Only fresh scat samples that had obviously come from 1 animal were collected. Samples were collected with a spoon, stored in plastic bags, and frozen immediately until processing. Each sample was thawed in water and washed through an elutriator (Bigg \& Olesiuk 1990) or a $0.495 \mathrm{~mm}$ sieve. All prey remains (fish bones, otoliths, cartilaginous parts, lenses, teeth, and cephalopod beaks, lenses, and pens) were recovered, dried, and stored in petri dishes. Using a reference collection, prey remains were identified to the lowest possible taxon by Pacific Identifications, Victoria, BC, Canada. The all-structures identification technique was used to identify all skeletal fragments and other hard parts to account for prey with completely digested otoliths or prey that might not be otherwise represented by otoliths (Lance et al. 2001, Browne et al. 2002).

Relative importance of each prey species was based on the frequency of occurrence (FO) in scat samples, calculated as the percentage of all scats in which a prey species occurred. Percentage FO was calculated by dividing the number of scats in which a prey item occurred by the total number of scats that contained identifiable prey remains and multiplying by $100 \%$ (Lance et al. 2001). Chi-square analysis was used to test for differences in FO of prey species in scat samples between seasons from 2001 to 2003. The analysis was limited to prey items occurring in at least $5 \%$ of scats across years. Diet diversity was calculated for each year and each season using Shannon's index of diversity $(H)$ where $p_{i}$ is the proportion of the $i$ th species in the sample (Zar 1999).

$$
H=-\sum_{i=1}^{k} p_{i} \ln p_{i}
$$

The fork length (FL) of herring and pollock consumed by sea lions was estimated by comparing sizes of bone structures found in scat with those of a reference collection maintained by Pacific Identifications. The FL estimates were generated by comparison with the same structure from comparative specimens of known size from the reference collection and grouped into size classes.

Prey availability-pelagic prey. Acoustic surveys were conducted near Benjamin Island in Favorite Channel, in Lynn Canal, SE Alaska (Fig. 1), monthly from June 2001 to May 2004 to estimate the availability of pelagic prey to Steller sea lions (Sigler \& Csepp in press). The transects occurred between Tee Harbor $\left(58^{\circ} 25^{\prime} \mathrm{N}, 134^{\circ} 46^{\prime} \mathrm{W}\right)$ and Vanderbilt Reef $\left(58^{\circ} 36^{\prime} \mathrm{N}, 135^{\circ} 01^{\prime} \mathrm{W}\right)$ and included pelagic and nearshore habitats with an average depth of $60 \mathrm{~m}$ (depth range $=5$ to $305 \mathrm{~m}$ ). Prey availability was estimated using a portable $38 \mathrm{kHz}$ Simrad echointegration system with a $12^{\circ}$ beam angle towed beside an $11 \mathrm{~m}$ commercial fishing vessel, FV 'Willi-

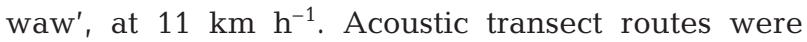
georeferenced using a Garmin global positioning system with $\pm 10 \mathrm{~m}$ accuracy. All surveys began in the morning after daybreak and concluded before dark to account for diel variation in acoustic density estimates (Huse \& Korneliussen 2000, Hjellvik et al. 2004) and to facilitate observations of foraging sea lions while collecting acoustic data. Midwater trawls from commercial fishing vessels were conducted quarterly to identify acoustic targets in the echograms and to collect length, weight, and species composition data.

The acoustic data were analyzed with an echointegrator that was used to sum the returning echoes from fish observed beneath the vessel. Acoustic data were classified by $0.183 \mathrm{~km}$ length intervals and $10 \mathrm{~m}$ depth intervals, and corrected for instrument calibration using the echo-integration software SonarData Echoview. The output of acoustic scattering (nautical area scattering coefficient, NASC) was used to compute fish density (MacLennan \& Simmons 1992). Average fish density was computed by substrata to account for differences in fish density within the survey area. Fish biomass equals average fish density in weight multiplied by the size of the substrata. Further details of methodology can be found in Sigler \& Csepp (in press).

Seasonal values of herring and pollock energy density (J. J. Vollenweider unpubl. data) were multiplied by monthly estimates of herring and pollock biomass, respectively, to obtain estimates of the total available energy per month available from herring and pollock. Available prey energy was compared to estimates of individual sea lion energy demands per day (Sigler et al. 2004), which were derived from consumption estimates and bioenergetic models for Steller sea lions (Winship et al. 2002). The estimated daily food ration was obtained by dividing the total food requirement of sea lions in Alaska by the estimated population size of sea lions (Winship et al. 2002). The estimated daily food ration (15.6 $\mathrm{kg} \mathrm{d}^{-1}$ ) was converted to daily energy ration using diet composition and prey density values from Winship et al. (2002) resulting in a computed ration of $79464 \mathrm{~kJ} \mathrm{~d}^{-1}$ (Sigler et al. 2004). 
Prey availability-nearshore prey. A companion study conducted nearshore prey surveys at 13 sites around Benjamin Island in winter (February to March) and summer (July) to estimate availability of nearshore prey species to Steller sea lions (Thedinga et al. 2006). Surveys were conducted in March (2002 and 2003) and July $(2001,2002,2003)$ using a combination of seining, jigging, and remotely operated vehicle (ROV). Sampling areas included intertidal and subtidal areas up to $100 \mathrm{~m}$ in depth and within $350 \mathrm{~m}$ of shore. Sites were selected in areas that could be seined, and were spatially distributed throughout the study area. The beach seine was $37 \mathrm{~m}$ long with variable mesh that tapered from $5 \mathrm{~m}$ wide at the center to $1 \mathrm{~m}$ wide at the ends. Jigging occurred at a depth range of 5 to $115 \mathrm{~m}$ at 18 stations at Benjamin Island with 3 people jigging at each station for 15 min. Captured fish were identified to species, enumerated, and weighed to the nearest $0.1 \mathrm{~kg}$. FL was measured to the nearest $\mathrm{mm}$ for up to 50 individuals of the selected species that were important in the diet of sea lions. An ROV was used to survey for fish that might not have been captured by jigging or seining. ROV dives were conducted at a depth of 125 to $255 \mathrm{~m}$ and extended towards the shore. Further details of methodology can be found in Thedinga et al. (2006).

\section{RESULTS}

\section{Sea lion seasonal abundance at Benjamin Island and along transects}

Benjamin Island was occupied by sea lions from October until June (Fig. 2) primarily by adult females with dependent young, juveniles, subadults and a few adult males. The pattern of sea lion occupation was consistent among years, with sea lions typically absent during summer and early fall, usually between July and September. The maximum number of sea lions ashore (range = 747 to 803 ) at Benjamin Island occurred between October and December (Fig. 2). Beginning in April in all years, the numbers of sea lions ashore at Benjamin Island began to decrease. Sea lions returned to Benjamin Island in October after the breeding season.

Steller sea lions were commonly observed in the water during acoustic surveys. A total of 366 Steller sea lions were observed on 61 occasions (Table 1). Steller sea lions were most common during fall and winter and infrequent during summer. Overall, $98 \%$ of Steller sea lion observations occurred from October to February.

\section{Sea lion diet}

A total of 56 prey items were identified from sea lion scat samples $(\mathrm{n}=787)$ collected at Benjamin Island (2001 to 2004); however, only 12 species occurred in at least $5 \%$ of scat samples. The 2 most common prey species found in scat samples, when pooled across years and seasons, were Pacific herring $(\mathrm{FO}=90 \%)$ and walleye pollock $(\mathrm{FO}=88 \%)$ followed in importance by skate Raja sp. (FO = 19\%), Pacific cod Gadus macrocephalus (FO =18\%), capelin Mallotus villosus $(\mathrm{FO}=17 \%)$, Pacific salmon Oncorhynchus sp. $(\mathrm{FO}=16 \%)$, cephalopods $(\mathrm{FO}=14 \%)$, northern lampfish Stenobrachius leucopsarus $(\mathrm{FO}=12 \%)$, sculpins (Cottidae) $(\mathrm{FO}=10 \%)$, arrowtooth flounder Atheresthes stomias (FO $=8 \%)$, eulachon $(\mathrm{FO}=8 \%)$, and Pacific hake Merluccius productus $(\mathrm{FO}=5 \%$ ) (Table 2, Fig. 3).

The FO of salmon, capelin, northern lampfish, sculpins, arrowtooth flounder, eulachon, and hake differed significantly among seasons; however, the FO of herring, pollock, skate, Pacific cod, and cephalopods did not differ significantly among seasons (Table 3, Fig. 3). The FO of salmon in scat was highest during October and December. The FO of capelin, northern lampfish, eulachon, and Pacific cod increased during April (Table 2).

The mean number of prey species per scat sample was $3.3 \pm 2.1(\mathrm{SD})$ and ranged from 1 to 13 species. There was a high co-occurrence of herring and pollock in the same scat sample (77.6\%). Diet diversity was higher in $2002(H=2.1)$ than in $2001(H=1.8)$ and 2003 $(H=1.8)$. Seasonal diet diversity was slightly higher in February $(H=1.9)$ and April $(H=2.1)$ than in October $(H=1.8)$ and December $(H=1.8)$.

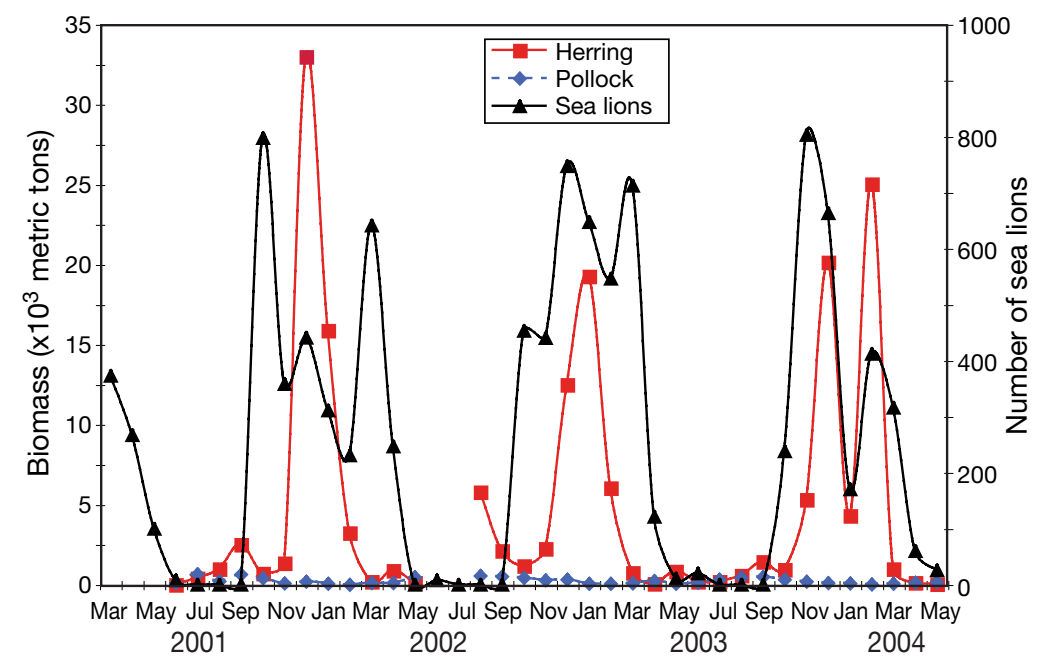

Fig. 2. Clupea pallasii, Theragra chalcogramma and Eumetopias jubatus. Monthly biomass of Pacific herring and walleye pollock and the number of sea lions ashore at Benjamin Island from March 2001 to May 2004 
Table 1. Number and percent of Steller sea lions counted in the water during monthly acoustic surveys. ns = no survey

\begin{tabular}{|lrrrrrr|}
\hline Month & 2001 & 2002 & 2003 & 2004 & Total & \% of total \\
\hline Jan & ns & 44 & 88 & 21 & 153 & 41.8 \\
Feb & ns & 18 & 9 & 54 & 81 & 22.1 \\
Mar & ns & 0 & 0 & 0 & 0 & 0.0 \\
Apr & ns & 0 & 0 & 3 & 3 & 0.8 \\
May & ns & 2 & 1 & 0 & 3 & 0.8 \\
Jun & 0 & 0 & 0 & ns & 0 & 0.0 \\
Jul & 0 & 0 & 0 & ns & 0 & 0.0 \\
Aug & 0 & 0 & 1 & ns & 1 & 0.3 \\
Sep & 1 & 0 & 0 & ns & 1 & 0.3 \\
Oct & 0 & 0 & 14 & ns & 14 & 3.8 \\
Nov & 20 & 12 & 4 & ns & 36 & 9.8 \\
Dec & 1 & 36 & 37 & ns & 74 & 20.2 \\
Total & 22 & 112 & 154 & 78 & 366 & 1 \\
\hline
\end{tabular}

A total of 5684 bone structures (including otoliths) from sea lion scat samples were compared to a reference collection of fish of known size to estimate FL of herring and pollock. Herring remains found in sea lion scat were predominantly of adult size (96\%) and ranged from 11 to $35 \mathrm{~cm}$ FL based on 3813 bone structures. Pollock remains found in sea lions scat included adult pollock (36\%) ranging from 34 to $54 \mathrm{~cm} \mathrm{FL,} \mathrm{juve-}$ nile pollock (51\%) ranging from 20 to $34 \mathrm{~cm} \mathrm{FL,} \mathrm{and}$ young-of-year pollock (10\%) ranging from 8 to $30 \mathrm{~cm}$ FL based on 1871 bone structures.

\section{Prey availability}

Pelagic prey biomass varied dramatically by month and by species. Herring and pollock were the most commonly detected prey species during acoustic surveys; however, herring occurred at densities several orders of magnitude greater than pollock. Herring biomass ranged from $6 \mathrm{t}$ (June 2001) to $32976 \mathrm{t}$ (December 2001). The biomass of herring exceeded $10000 \mathrm{t}$ in December and January in 2001/2002 and 2002/2003, and in December and February in 2003/2004 (Table 4). In contrast, pollock biomass ranged from $3 \mathrm{t}$ (February 2002) to 655 t (July 2001) (Table 4). Although herring and walleye pollock dominated the surveys, the seasonality of the 2 species differed (Fig. 2). Large schools of herring began to form in November and were present through February in all years. In contrast, pollock was available throughout the year but did not vary as dramatically as herring (Fig. 2). Maximum pollock biomass occurred in late spring and summer. Averaged across all months, herring represented $81 \%$ of available biomass, whereas walleye pollock accounted for only $19 \%$ of the biomass. Hake contributed to the remaining $1 \%$ in several months.

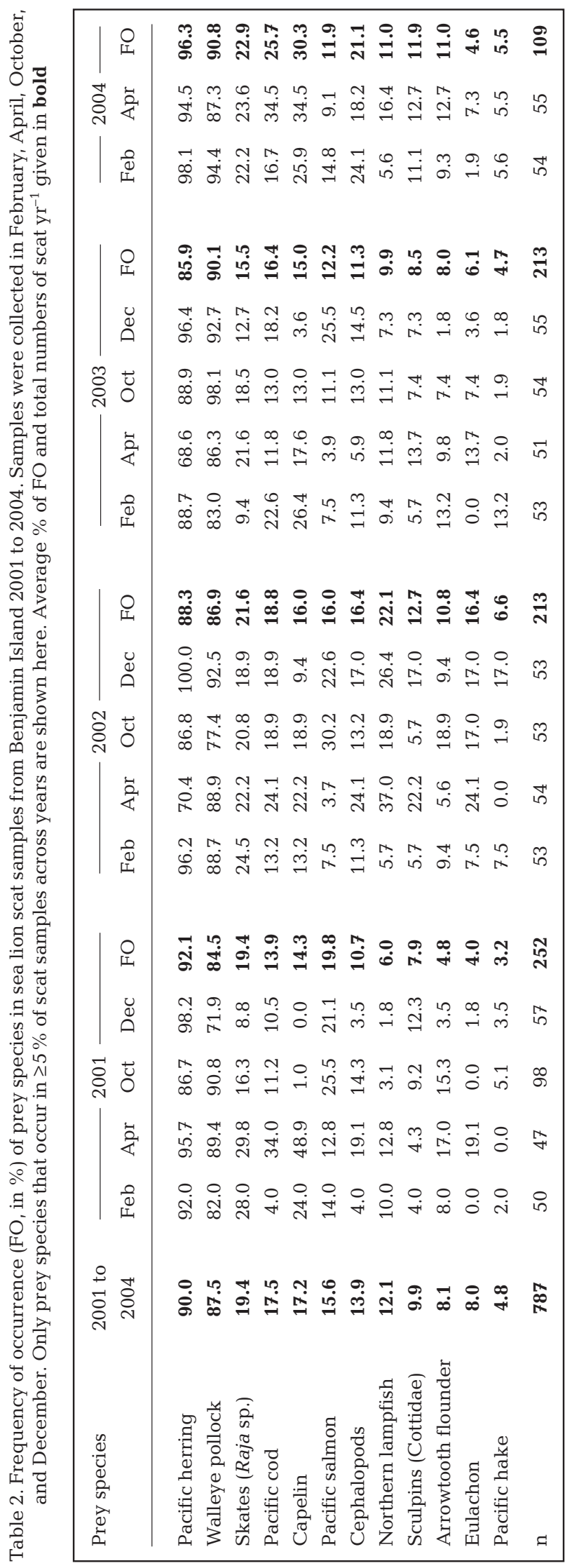




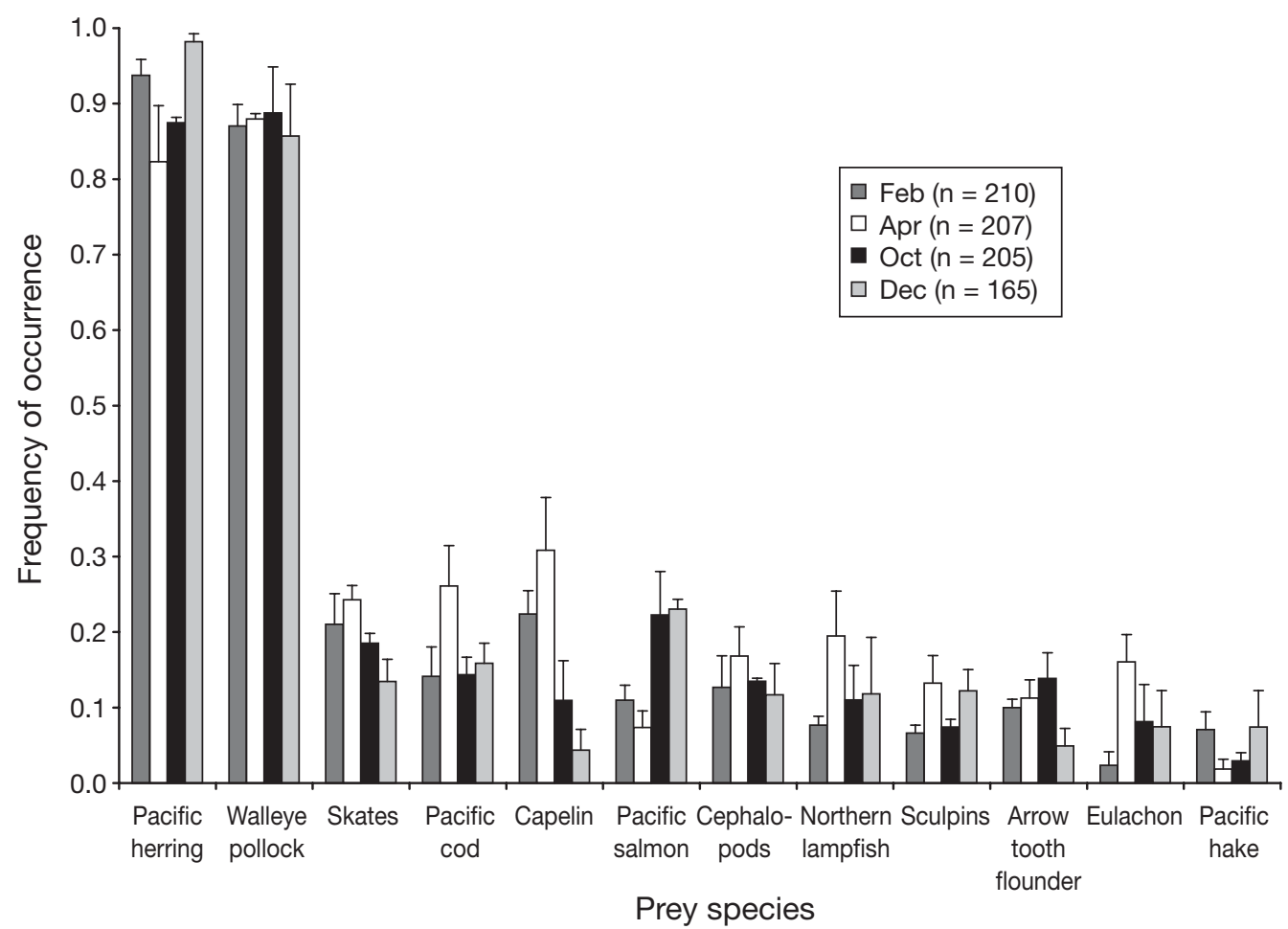

Fig. 3. Eumetopias jubatus. Frequency of occurrence of prey species in Steller sea lion scat samples collected in February, April, October and December (2001 to 2004) from Benjamin Island. Only prey species that occur in $\geq 5 \%$ of scat samples across years are shown

Midwater trawls targeting herring and pollock were dominated by catches of these species. Herring comprised $87 \%$ of the catch by weight when herring was targeted and pollock comprised $84 \%$ of the catch by weight when pollock was targeted (Sigler \& Csepp in press). Herring caught in trawl surveys ranged from 8 to $27 \mathrm{~cm}$ FL (n = 2809) and available pollock size ranged from 10 to $69 \mathrm{~cm}$ FL ( $\mathrm{n}=15$ 873).

Table 3. Difference in frequency of occurrence of prey species in Steller sea lion scat samples between February, April, October, and December during 2001-2003. Chi-square analysis was limited to prey species occurring in $\geq 5 \%$ of scat samples across years. $\chi_{0.05,3}^{2}=7.815$

\begin{tabular}{|lcc|}
\hline Prey species & $\chi^{2}$ & $\mathrm{p}$ \\
\hline Pacific herring & 4.03 & 0.26 \\
Walleye pollock & 0.29 & 0.96 \\
Skates & 5.00 & 0.17 \\
Pacific cod & 6.00 & 0.11 \\
Capelin & 42.00 & $<0.001$ \\
Pacific salmon & 23.00 & $<0.001$ \\
Cephalopods & 4.00 & 0.26 \\
Northern lampfish & 13.00 & $<0.005$ \\
Sculpins & 7.85 & $<0.05$ \\
Arrowtooth flounder & 16.00 & $<0.005$ \\
Eulachon & 28.00 & $<0.001$ \\
Pacific hake & 11.25 & $<0.025$ \\
\hline
\end{tabular}

Herring accounted for the majority of energy available to sea lions in most months. Energy available from herring was highest from December to February (Fig. 4). During winter, herring accounted for $99 \%$ of the energy available from pelagic prey surveys (Sigler \& Csepp in press). The maximum value of available herring energy along transects was 285 Tera Joules $\left(\mathrm{TJ}=10^{12} \mathrm{~J}\right)$, equivalent to 3.6 million daily rations for sea lions (Table 4). The seasonal occupation of Benjamin Island by sea lions coincided with peaks in estimated energy available from herring (Fig. 4). In contrast, the maximum value of energy available from pollock was $2.8 \mathrm{TJ}$, equivalent to 35000 daily rations for sea lions (Table 4). Although the contribution of pollock to the total energy content was orders of magnitude less than herring, pollock alone could provide enough daily rations for sea lions at Benjamin Island.

Nearshore prey catches were much greater during summer than in winter around Benjamin Island (Thedinga et al. 2006). Rock sole Lepidopsetta bilineata, buffalo sculpin Enophrys bison, and pink salmon Oncorhynchus gorbuscha were the most common species in seine catches in winter and were the most frequent species captured by jigging. In summer, pollock, herring, and Pacific sand lance Ammodytes hexapterus were the most common species in seine catches, whereas armorhead sculpin Gymnocanthus galeatus 
Table 4. Biomass, total energy content, and the estimated number of daily energy rations of herring and pollock available to Steller sea lions at Benjamin Island, SE Alaska

\begin{tabular}{|c|c|c|c|c|c|c|}
\hline Date & $\begin{array}{c}\text { Herring } \\
\text { biomass } \\
\text { (t) }\end{array}$ & $\begin{array}{l}\text { Pollock } \\
\text { biomass } \\
\text { (t) }\end{array}$ & $\begin{array}{l}\text { Herring energy } \\
\text { content } \\
\text { (TJ) }\end{array}$ & $\begin{array}{l}\text { Pollock energy } \\
\text { content } \\
\text { (TJ) }\end{array}$ & $\begin{array}{l}\text { No. of daily } \\
\text { energy rations from } \\
\text { herring (thousands) }\end{array}$ & $\begin{array}{l}\text { No. of daily } \\
\text { energy rations from } \\
\text { pollock (thousands) }\end{array}$ \\
\hline 2001 June & 6 & 102 & 0.1 & 0.4 & 1 & 5 \\
\hline July & 406 & 655 & 3.7 & 2.7 & 46 & 34 \\
\hline August & 994 & 225 & 9.0 & 1.0 & 113 & 12 \\
\hline September & 2506 & 637 & 22.6 & 2.8 & 284 & 35 \\
\hline October & 716 & 415 & 6.5 & 1.7 & 81 & 21 \\
\hline November & 1347 & 79 & 11.6 & 0.4 & 146 & 4 \\
\hline December & 32976 & 199 & 284.9 & 0.9 & 3585 & 12 \\
\hline 2002 January & 15835 & 73 & 136.8 & 0.3 & 1722 & 4 \\
\hline February & 3367 & 3 & 19.3 & 0.0 & 243 & 0 \\
\hline March & 203 & 104 & 1.2 & 0.4 & 15 & 5 \\
\hline April & 883 & 113 & 5.1 & 0.4 & 64 & 6 \\
\hline May & 139 & 473 & 0.8 & 1.7 & 10 & 22 \\
\hline August & 5795 & 553 & 61.4 & 2.4 & 772 & 30 \\
\hline September & 2129 & 523 & 22.6 & 2.3 & 284 & 29 \\
\hline October & 1173 & 422 & 12.4 & 1.8 & 156 & 23 \\
\hline November & 2245 & 287 & 19.5 & 1.3 & 245 & 16 \\
\hline December & 12492 & 319 & 108.3 & 1.4 & 1363 & 18 \\
\hline 2003 January & 19272 & 74 & 167.1 & 0.3 & 2103 & 4 \\
\hline February & 6117 & 55 & 35.1 & 0.2 & 442 & 3 \\
\hline March & 757 & 86 & 4.3 & 0.3 & 55 & 4 \\
\hline April & 59 & 242 & 0.3 & 0.9 & 4 & 11 \\
\hline May & 837 & 61 & 4.8 & 0.2 & 60 & 3 \\
\hline June & 186 & 126 & 1.1 & 0.5 & 13 & 6 \\
\hline July & 191 & 321 & 1.9 & 1.3 & 23 & 17 \\
\hline August & 580 & 457 & 5.6 & 1.9 & 71 & 24 \\
\hline September & 1448 & 455 & 14.1 & 1.9 & 177 & 24 \\
\hline October & 941 & 313 & 9.2 & 1.3 & 115 & 16 \\
\hline November & 5309 & 203 & 47.2 & 0.9 & 594 & 12 \\
\hline December & 20139 & 106 & 179.0 & 0.5 & 2253 & 6 \\
\hline 2004 January & 4319 & 80 & 38.4 & 0.4 & 483 & 4 \\
\hline February & 25026 & 21 & 143.7 & 0.1 & 1808 & 1 \\
\hline March & 988 & 60 & 5.7 & 0.2 & 71 & 3 \\
\hline April & 128 & 126 & 0.7 & 0.4 & 9 & 6 \\
\hline May & 39 & 177 & 0.2 & 0.6 & 3 & 8 \\
\hline
\end{tabular}

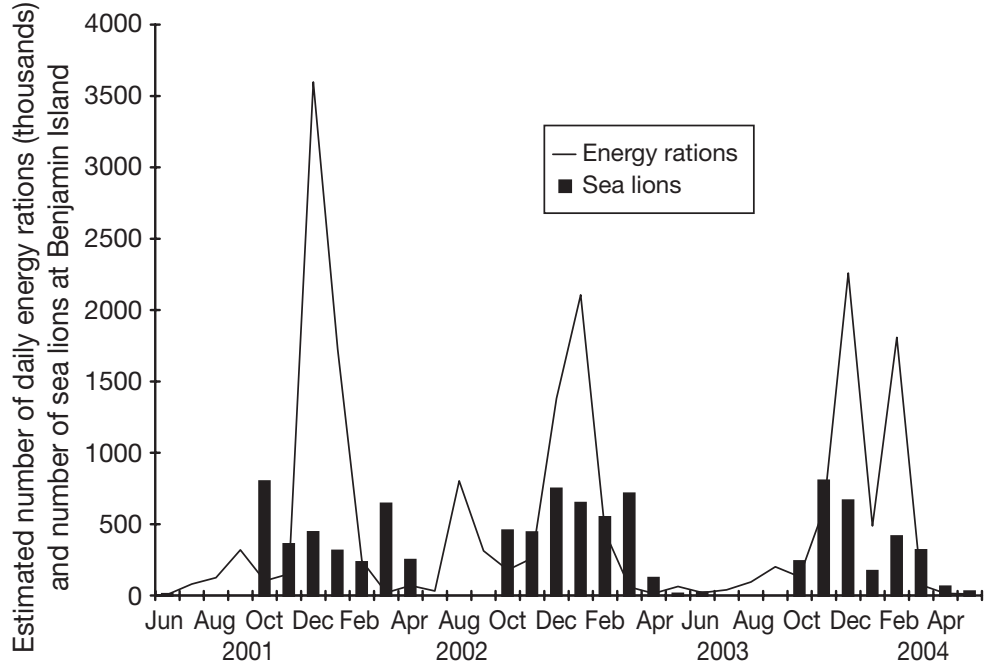

Fig. 4. Clupea pallasii, Theragra chalcogramma, and Eumetopias jubatus. Estimated number of sea lion daily energy rations available from herring and pollock in relation to the number of sea lions hauled out at Benjamin Island from March 2001 to May 2004 was the most frequently captured by jigging (Thedinga et al. 2006). Most species captured by seining were $<17 \mathrm{~cm}$ FL, yet sea lions at Benjamin Island consumed few species that were $<17 \mathrm{~cm}$ FL.

The most common species observed from the ROV included juvenile gadids, Pacific sand lance, dusky rockfish Sebastes ciliatus, and Pacific snake pricklebacks Lumpenus sagitta. Seven species were observed with the ROV that were not captured either by seining or jigging and included Atka mackerel Pleurogrammus monopterygius, Puget Sound rockfish $S$. emphaeus, silvergray rockfish $S$. brevispinus, tiger rockfish $S$. nigrocinctus, yelloweye rockfish $S$. ruberrimus, rex sole Glyptocephalus zachirus, and Alaska skate Bathyraja parmifera (Thedinga et al. 2006). 


\section{Seasonal abundance and diet of sea lions in relation to prey availability}

Large numbers of sea lions occupied Benjamin Island during the non-breeding season when herring biomass was highest. Peaks in sea lion abundance at Benjamin Island and in the water along acoustic transects occurred between October and March. Pacific herring was the most common prey species in sea lion diet and comprised over $81 \%$ of the available pelagic prey biomass and $96 \%$ of the energy encountered during pelagic surveys near Benjamin Island. In contrast, walleye pollock accounted for $19 \%$ of the available prey biomass but was only slightly less common in sea lion diet than Pacific herring. For all years combined, there was a significant relationship between (log) number of sea lions and (log) herring biomass (t) $\left(\mathrm{r}^{2}=\right.$ 0.55, $F_{1,23}=27.11, \mathrm{p}<0.0001$ ) (Fig. 5a), but there was no relationship with (log) pollock biomass $\left(\mathrm{r}^{2}=0.01\right.$, $F_{1,23}=0.25, \mathrm{p}=0.62$ ) (Fig. 5b). Pollock biomass increased when sea lions were absent from Benjamin Island from May through September (Fig. 2). As her-

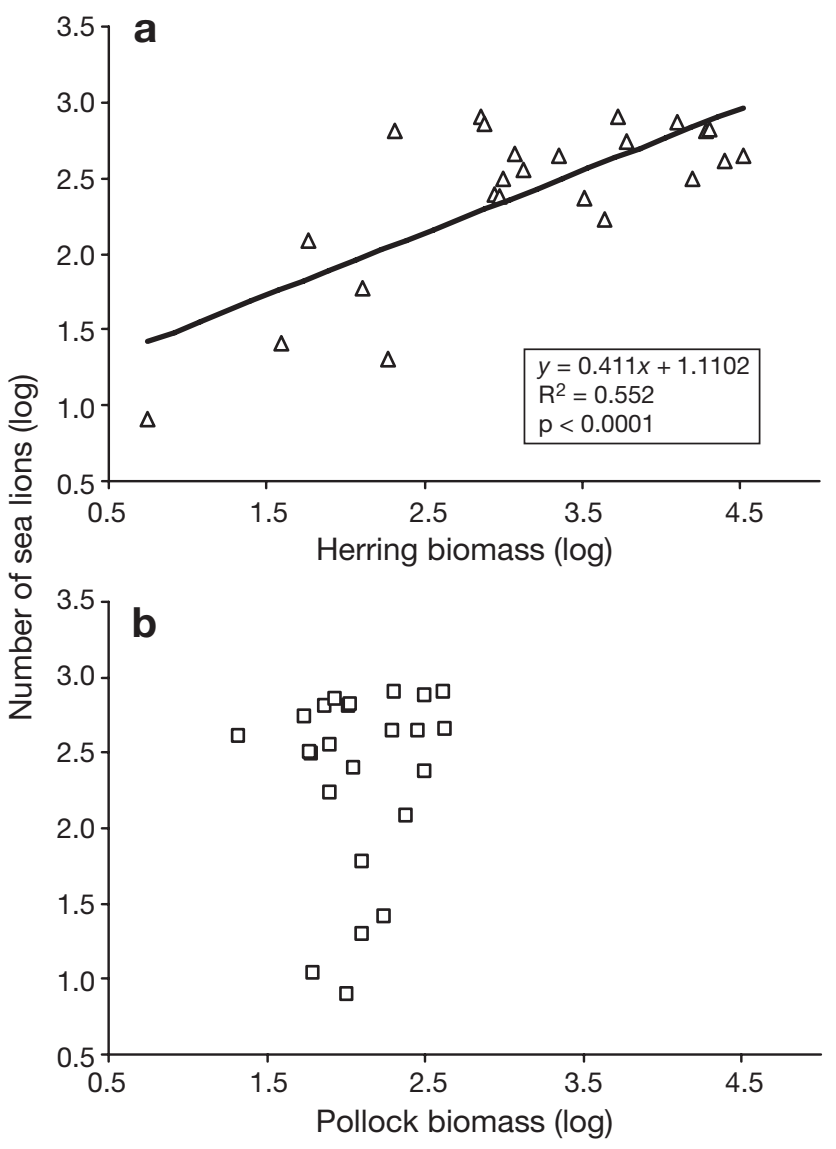

Fig. 5. Eumetopias jubatus, Clupea pallasii and Theragra chalcogramma. Relationship between (a) herring biomass (log) and (b) pollock biomass (log) and number of Steller sea lions $(\log )$ at Benjamin Island ring biomass began to decline in late winter, springspawning prey species such as Pacific cod, capelin, northern lampfish, and eulachon increased in FO in the diet of sea lions and herring decreased (Fig. 3). When herring biomass declined around Benjamin Island in spring, the number of sea lions declined (Fig. 2); however, the number of sea lions increased in Berners Bay, located approximately $22 \mathrm{~km}$ north of Benjamin, which is the site of a spring-spawning aggregation of eulachon (Sigler et al. 2004).

The size of herring consumed by sea lions (8 to $27 \mathrm{~cm}$ FL) overlapped with the size of herring detected during trawl surveys (11 to $35 \mathrm{~cm}$ FL). The majority of pollock consumed by sea lions (20 to $54 \mathrm{~cm}$ FL) was similar to the size of pollock detected by trawls (10 to $69 \mathrm{~cm}$ FL); however, there were smaller pollock ( $<20 \mathrm{~cm} \mathrm{FL)}$ detected by trawls that were not found in sea lion scat.

Few fish species in seine catches in nearshore areas were found in the sea lion diet samples and most fish species were smaller (Thedinga et al. 2006) than the average size of prey consumed by sea lions at Benjamin Island. Juvenile pink salmon $(<10 \mathrm{~cm} \mathrm{FL)} \mathrm{comprised}$ 12.3 and $16.2 \%$ of nearshore seine catch in March of 2002 and 2003, respectively, but sea lions consume Pacific salmon ranging from 16 to $90 \mathrm{~cm}$ FL. Sea lions consumed Pacific cod ranging from 16 to $80 \mathrm{~cm}$ FL; however, $96 \%$ were of adult size. Pacific cod captured by jigging in nearshore areas ranged from 14 to $49 \mathrm{~cm}$ FL, whereas cod from seine catches were primarily juveniles ( 3 to $19 \mathrm{~cm}$ FL). Fish species such as cottids were found in seine catches and occurred in sea lion diet (Thedinga et al. 2006). The most common cottids found in sea lion scat samples were Pacific staghorn sculpin Leptocottus armatus $(\mathrm{FO}=3.9 \%)$ and great sculpin $\mathrm{My}$ oxocephalus polyacanthocephalus $(\mathrm{FO}=2.2 \%)$. Most staghorn sculpins (84\%) consumed by sea lions were adults and ranged between 20 and $44 \mathrm{~cm}$ FL and overlapped with the size (16 to $30 \mathrm{~cm} \mathrm{FL)} \mathrm{of} \mathrm{staghorn}$ sculpins caught in nearshore seine catches. Great sculpins found in sea lion scat were also primarily adults (16 to $64 \mathrm{~cm} \mathrm{FL);} \mathrm{however,} \mathrm{adult} \mathrm{fish} \mathrm{(25} \mathrm{to} 47 \mathrm{~cm}$ FL) were only captured in nearshore jig sampling.

\section{DISCUSSION}

\section{Seasonal availability of prey resources for sea lions}

Large numbers of sea lions occupied Benjamin Island during the non-breeding season from October to April, when herring biomass was highest, and there was a positive correlation with the biomass of herring and the number of sea lions. The seasonal use of Benjamin Island by sea lions is associated with the avail- 
ability of densely aggregated, overwintering herring. Herring is available for several months, around Benjamin Island, and can sustain sea lions that come ashore at Benjamin Island for up to 6 mo (October to March). The energy density of herring is highest in fall and early winter (Vollenweider 2005), when herring are most abundant near Benjamin Island and thus may confer energetic benefits to sea lions. In April, when herring biomass decreases and herring energy density decreases, the number of sea lions begins to decrease. Herring provides an abundant, densely aggregated, high-energy resource for sea lions close to the terrestrial haulout site, which may be particularly important for adult females with dependent pups.

Overwintering herring were seasonally predictable near Benjamin Island from 2001 to 2004. Furthermore, aggregations of overwintering herring were documented in the same general area from 1973 to 1975 (Carlson 1980), suggesting that herring have been using the same area for at least 3 decades. Herring usually follow the same migration paths and use the same overwintering areas year after year (Corten 2002). In spring, between March and May in SE Alaska, herring move to spawning areas (Carlson 1980). During summer, herring typically move to feeding areas, many of which are located along the outer coast of SE Alaska (Rounsefell 1930).

Although there was no relationship between the biomass of pollock and the number of sea lions, pollock was only slightly less common than herring in sea lion diet. The availability of pollock throughout the year may provide a maintenance diet for sea lions when other seasonal prey resources are not available. Pollock may be consumed by sea lions for much of the year; however, when herring are aggregated in areas close to Benjamin Island, herring may be more energetically rewarding than pollock because they are more densely aggregated and higher in energy density and lipid content than pollock (Iverson et al. 2002, Vollenweider 2005). Furthermore, a mixed diet of pollock and herring may confer benefits over a single-species diet by increasing digestible energy intake (Trumble \& Castellini 2005).

Pollock occurred in much lower biomass than did herring, particularly in winter when sea lions were at Benjamin Island, yet pollock was one of the most common prey consumed and were present throughout the winter. Possible explanations include different spatial distributions of pollock and herring in the survey area. The survey area is an important herring overwintering area and herring are concentrated there seasonally, whereas pollock are common both inside and outside the survey area (based on limited sampling outside the survey area). In addition, captive studies have shown that pollock remains occur in significantly more sea lion scats than other prey species and recovery rates for pollock are 3-fold that of herring (Tollit et al. 2003). Cottrell \& Trites (2002) found that on the average the number of pollock hard parts recovered from the scat of captive sea lions was 31.2 per pollock, in contrast to only 7.9 per herring. Passage rates are higher for pollock than herring, which may tend to overestimate pollock and underestimate herring in sea lion diet. Pollock typically have larger more robust otoliths that are able to withstand the digestive process better than the smaller otoliths of herring (Tollit et al. 2003).

Although pollock biomass increased primarily during summer at Benjamin Island, the energy density of pollock is highest in winter (Vollenweider 2005), when sea lions occupy Benjamin Island. In other areas of Alaska, pollock was the dominant prey species of sea lions (Pitcher 1981, Merrick et al. 1997, Sinclair \& Zeppelin 2002); however, small schooling fish, not pollock, were the dominant prey items found in sea lions taken in Alaska from 1958 to 1962 (Fiscus \& Baines 1966).

The size of prey consumed by pinnipeds is likely underestimated due to erosion of hard parts during the digestive process (e.g. da Silva \& Neilson 1985, Tollit et al. 2004). Underestimation of prey size, which is influenced by fish species and size (Bowen 2000), may account for differences observed in the size of prey consumed in relation to the available detected during trawl surveys. Although the size of pollock consumed by sea lions was similar to the size of pollock available in trawl surveys, the average size reduction for different pollock structures ranged from 12.2 to $24.7 \%$ in captive feeding trials with Steller sea lions (Tollit et al. 2004).

\section{Importance of other seasonally occurring prey species}

Although pollock and herring dominated the diet of sea lions during all seasons, other seasonally available prey species, such as spring-spawning forage fish and Pacific salmon, were important for shorter periods. The frequency of occurrence of forage fish species, with the exception of herring, increased in the sea lion diet during April and consequently prey diversity increased. Spawning aggregations of forage fish provide densely aggregated, high-energy prey for Steller sea lions for brief time periods and may influence haulout use by sea lions (Sigler et al. 2004, Womble et al. 2005). The spawning season of many forage fish species occurs between March and May in SE Alaska just prior to the breeding season of Steller sea lions.

Eulachon provide an important high-energy prey pulse for Steller sea lions at Benjamin Island when herring biomass begins to decrease in spring. Other than northern lampfish, eulachon are higher in lipid content than any other sea lion prey item (Iverson et al. 2002, 
Vollenweider 2005). Mean lipid content for eulachon in SE Alaska was $16.30 \pm 4.10 \%$ and was as high as $28.9 \%$ (Vollenweider 2005). Overall, eulachon were found in only $8 \%$ of scat samples from 2001 to 2004, although during April 2002 the frequency of occurrence of eulachon in sea lion scat was as high as $24.1 \%$. Eulachon may be underestimated in scat samples from Benjamin Island because sea lions raft near spawning aggregations and may not regularly return to the haulout to defecate (Womble et al. 2005). In addition, during captive feeding trials with California sea lions the average recovery rate for eulachon otoliths was only $46.5 \%( \pm 13.7)$ (Orr \& Harvey 2001) further contributing to the underestimation of eulachon in the sea lion diet.

Although eulachon does not appear to be an important prey item for sea lions in other areas of Alaska (Pitcher 1981, Merrick et al. 1997, Sinclair \& Zeppelin 2002), observations from Lynn Canal near Benjamin Island suggest that eulachon may play an important role in the seasonal foraging ecology of sea lions in the area (Marston et al. 2002, Sigler et al. 2004, Womble et al. 2005). In 2004, eulachon were found in $100 \%$ of scat samples $(\mathrm{n}=10)(\mathrm{J} . \mathrm{N}$. Womble unpubl. data) collected at a terrestrial haulout site in Berners Bay in Lynn Canal near a spawning aggregation of eulachon. In addition, juvenile sea lions captured and tagged at Benjamin Island were observed to move to areas of known high eulachon concentrations in Berners Bay and northern Lynn Canal during the spring spawning season of 2003 (National Marine Fisheries Service [NMFS] unpubl. data).

Capelin was seasonally important in sea lion diet in April (up to FO $=48.9 \%$ ) and overall occurred in $17 \%$ of scat samples. Although not as high in energy content as eulachon and herring, the mean energy value of capelin in SE Alaska was $4.51 \pm 1.04 \mathrm{~kJ} \mathrm{~g}^{-1}$ (Vollenweider 2005). As with eulachon, the smaller and more fragile otoliths of capelin were recovered at a much lower rate $(10.0 \pm 7.1 \%)$ in captive trials with California sea lions (Orr \& Harvey 2001); therefore it is likely the use of capelin by sea lions at Benjamin Island may be underestimated. Capelin spawn in spring and summer in SE Alaska (Table 5) and spawning occurs in northern Lynn Canal in spring (K. Brownlee pers. comm. 2002). In Prince William Sound, capelin was primarily consumed by sea lions in spring and summer (Pitcher 1981). Prior to the 1970s, capelin was an important component of sea lion diet in the Gulf of Alaska and Unimak Pass (Fiscus \& Baines 1966, Pitcher 1981); however, in sea lion scat samples collected from 1990 to 1998, capelin occurred in low frequencies (Sinclair \& Zeppelin 2002).

Northern lampfish occurrence in sea lions scats also increased during spring with a particularly dramatic increase in April 2002 (FO = 37\%). Northern lampfish have the highest lipid content $(46.3 \pm 4.40 \%$ dry mass $)$ (Anthony et al. 2000) of any sea lion prey species and are one of the most abundant species caught in trawls in the mesopelagic zone of the Gulf of Alaska (Purcell 1996). Typically they inhabit depths of 300 to $600 \mathrm{~m}$ during the day with vertical migrations to $50 \mathrm{~m}$ at night (Frost \& McCrone 1979). We commonly detected northern lampfish in our acoustic surveys, but we did not estimate their abundance because they were mixed with Pacific hake and have low acoustic reflectivity.

Northern lampfish may play an important seasonal role in the foraging ecology of sea lions, given their extremely high lipid content and accessibility. In Muir Inlet, a glacial fiord west of Lynn Canal, northern lampfish have been found as shallow as 10 to $15 \mathrm{~m}$ during the day (Abookire et al. 2001), which would make them easily accessible to Steller sea lions. In other areas, such as the Southern Ocean, myctophids are high in lipid content, exploited by several predators, and play an important role in food webs (Lea et al. 2002).

The FO of salmon increased in October and December and coincided with the run timing of fall spawning salmon (Table 5). During fall and early winter (September to December) coho salmon Oncorhynchus kisutch and chum salmon $O$. keta are returning to rivers in

Table 5. Prey species that differed significantly in frequency of occurrence by season, month of maximum frequency of occurrence $\left(\mathrm{FO}_{\max }\right)$, and the season during which each species spawns

\begin{tabular}{|c|c|c|c|c|c|c|c|c|}
\hline \multirow[b]{2}{*}{ Prey species } & \multicolumn{2}{|c|}{$-2001-$} & \multicolumn{2}{|c|}{$-2002-$} & \multicolumn{2}{|c|}{$-2003-$} & \multirow{2}{*}{$\begin{array}{l}\text { Spawning } \\
\text { season }\end{array}$} & \multirow[t]{2}{*}{ Source } \\
\hline & Month & $\mathrm{FO}_{\max }$ & Month & $\mathrm{FO}_{\max }$ & Month & $\mathrm{FO}_{\max }$ & & \\
\hline Capelin & Apr & 48.9 & Apr & 22.2 & Feb & 26.4 & $\begin{array}{l}\text { Spring and } \\
\text { Summer }\end{array}$ & $\begin{array}{l}\text { M. Arimitsu (USGS-BRD, } \\
\text { Juneau, AK) pers. comm. }\end{array}$ \\
\hline Pacific salmon & Oct & 25.5 & Oct & 30.2 & Dec & 25.5 & Summer and fall & Groot \& Margolis (1991) \\
\hline Northern lampfish & Apr & 12.8 & Apr & 37.0 & Apr & 11.8 & Winter to spring & Smoker \& Pearcy (1970) \\
\hline Sculpins & Dec & 12.3 & Apr & 22.2 & Apr & 13.7 & Winter & Hart (1973) \\
\hline Arrowtooth flounder & Apr & 17.0 & Oct & 18.9 & Feb & 13.2 & Winter & Rickey (1995) \\
\hline Eulachon & Apr & 19.1 & Apr & 24.1 & Apr & 13.7 & Spring & Hart (1973) \\
\hline Hake & Oct & 5.1 & Dec & 17.0 & Feb & 13.2 & Winter & Hart (1973) \\
\hline
\end{tabular}


northern Lynn Canal to spawn (Cline 1982) and are available to sea lions as high-energy prey. Sea lions may intercept salmon as the fish migrate by Benjamin Island en route to spawning rivers in northern Lynn Canal. In contrast, in both Prince William Sound and in the western Alaska, salmon were consumed by sea lions primarily in summer, likely reflecting the spawning period of salmon in those areas (Pitcher 1981, Sinclair \& Zeppelin 2002). The importance of salmon in the diet may be underestimated because the recovery rate $(13$ to $86 \%$ ) of salmon structures in scat was much lower than that of pollock (22 to $156 \%$ ) from a captive study of Steller sea lions (Tollit et al. 2003).

Skates (Raja sp.) were the third most common prey group and were typically more common in February and April. During pelagic prey surveys, there was no directed sampling for on-bottom species such as skates near Benjamin Island; however, in Frederick Sound, approximately $160 \mathrm{~km}$ south of Benjamin Island, sandpaper skates Bathyraja interrupta, Alaska skates B. parmifera, longnose skates Raja rhina, and big skates $R$. binoculata, were the most frequently caught species in longline catches (M. F. Sigler unpubl. data). Although skates were a common diet item for sea lions, the energy content of skates is relatively low compared to herring (Logerwell \& Schaufler 2005).

\section{Foraging tactics and energetic costs}

Although herring and pollock were the primary pelagic species available to sea lions and corresponded to the most common prey species in sea lion diet, sea lions likely use different foraging tactics for each of these species. Foraging for different prey types can influence foraging strategies and encounter rates (Engen \& Stenseth 1984), which ultimately influence foraging costs. For example, the foraging tactics of harbor seals Phoca vitulina differed among prey types and these tactics had energetic consequences that likely affected prey profitability (Bowen et al. 2002). Pursuit/handling time for harbor seals was greater for demersal flounder than for schooling sand lance (Bowen et al. 2002).

Ultimately, given the differences in prey density, energy density, and depth ranges for herring and pollock, it would be necessary to determine the cost of foraging for each of these prey types, as the foraging tactics employed by sea lions are likely to be different, thus influencing prey profitability. Herring are schooling fish that are typically found in densely aggregated schools along the bottom or in the water column. In contrast, juvenile pollock are more loosely aggregated. Average depths for herring and juvenile pollock were $<100 \mathrm{~m}$ water depth, whereas adult pollock aver- age depths were from 150 to 200 m (Sigler \& Csepp in press).

In contrast to herring, most of the nearshore fish species are not densely aggregated and may require a different foraging tactic for sea lions in nearshore areas. Although some prey species, such as Pacific cod, skates, and sculpins, found in nearshore areas were common in the sea lion diet, in general there was very little overlap with fish species or fish size caught in nearshore areas and the fish species found in sea lion scat. Nearshore seine and jig catches in winter around Benjamin Island contained far fewer fish than seine and jig catches in summer (Thedinga et al. 2006), suggesting that the nearshore area may not be a cost-efficient place to forage in winter.

\section{Implications of seasonal availability of prey to marine predators}

If prey patches are profitable season after season, experience could allow predators to locate prey patches more efficiently in following trips (Miliniski 1994), as marine predators may use a combination of local enhancement and memory to locate prey patches around a central place (Davoren et al. 2003). Experimental studies with California sea lions have demonstrated that individual sea lions have the ability to remember over several years (Reichmuth Kastak \& Schusterman 2002). Herring return to the same wintering grounds year after year (Carlson 1980); therefore, it is likely that individual sea lions may learn and remember where the highly predictable prey patches are located and return to a terrestrial haulout site close to the prey patches. Observations of adult female Steller sea lions with pups that were permanently marked at their birth rookeries suggest that some of the same sea lions return to Benjamin Island year after year (K. W. Pitcher pers. comm. 2004). Given the lengthy lactation period of Steller sea lions, access to predictable densely aggregated prey resources in winter around Benjamin Island may be critical as energetic demands increase for females with growing dependent pups during winter and spring (Winship et al. 2002). In Tysfjord, Norway, killer whales Orcinus orca return to feed on spring-spawning Atlantic herring Clupea harengus year after year (Similä et al. 1996). Other pinniped species, including Antarctic fur seals Arctocephalus gazella and northern elephant seals Mirounga angustirostris, make foraging trips to the same areas year after year (LeBoeuf et al. 2000, Bonadonna et al. 2001).

The seasonal availability of densely aggregated, energy-rich prey resources influences the seasonal abundance and diet of sea lions at Benjamin Island. 
Sea lions exhibit similar patterns of seasonal occupation at other terrestrial haulout sites in SE Alaska (Womble 2003) and these patterns may be related to the seasonal movement of herring or other seasonally available prey species. The availability of prey resources can vary temporally and spatially at various scales, so further integrated, fine-scale investigations of the influence of prey abundance and availability on sea lion abundance, distribution, diet, and movements are warranted throughout their range. Elucidating factors that may influence the abundance and distribution of sea lions may provide insight into declines of sea lions in other parts of their range. Marine predators likely depend upon seasonally available prey to meet energy demands throughout the year. Ultimately, understanding the role that the seasonal availability of prey species plays in the ecology of marine predators is an important step in furthering our understanding of factors that may regulate marine predator populations.

Acknowledgements. J. Norvell (Tal Air) and P. Ord (FV 'Williwaw') provided safe and expert pilotage throughout the study. K. Blejwas, D. Csepp, M. Kunnasranta, J. Scott-Ashe, K. Smikrud, J. Vollenweider, K. R. White, K. S. White, B. Williams and numerous volunteers assisted in data collection and logistical support. S. Crockford (Pacific Identifications) and P. Cottrell (Seal Research) provided expertise in identification and processing of prey remains. B. Herbold and P. Johnson provided library support. Earlier drafts of the manuscript benefited from comments from M. Arimitsu, G. Duker, M. Lea, J. Pella, P. Rigby, D. Tollit, J. Vollenweider, M. Willson, and 4 anonymous reviewers. J.N.W. was supported by an Elmer Rasmuson Fisheries Research Fellowship. The research described in this paper was supported by the Alaska Fisheries Science Center-Auke Bay Laboratory and the University of Alaska. This study was carried out under MMPA/ESA Permit No. 782-1532-02.

\section{LITERATURE CITED}

Abookire AA, Piatt JF, Speckman SG (2001) A nearsurface, daytime occurrence of two mesopelagic fish species (Stenobrachius leucopsarus and Leuroglossus schmidti) in a glacial fiord. Fish Bull US 100:376-380

Anthony JA, Roby DD, Turco KR (2000) Lipid content and energy density of forage fishes form the northern Gulf of Alaska. J Exp Mar Biol 248:53-78

Bigg MA, Olesiuk PF (1990) An enclosed elutriator for processing marine mammal scats. Mar Mamm Sci 6:350-355

Bonadonna F, Lea MA, Dehorter O, Guinet C (2001) Foraging ground fidelity and route-choice tactics of a marine predator: the Antarctic fur seal Artocephalus gazella. Mar Ecol Prog Ser 223:287-297

Bowen WD (2000) Reconstruction of pinniped diets: accounting for complete digestion of otoliths and cephalopod beaks. Can J Fish Aquat Sci 57:898-905

Bowen WD, Tully D, Boness DJ, Bulheier BM, Marshall GJ (2002) Prey-dependent foraging tactics and prey profitability in a marine mammal. Mar Ecol Prog Ser 244: 235-245

Boyd IL, McCafferty DJ, Reid K, Taylor R, Walker TR (1998)
Dispersal of male and female Antarctic fur seals (Arctocephalus gazella). Can J Fish Aquat Sci 55:845-852

Browne P, Laake J, De Long RL (2002) Improving pinniped diet analyses through identification of multiple skeletal structures in fecal samples. Fish Bull US 100:423-433

Calkins DG, Pitcher KW (1982) Population assessment, ecology and trophic relationships of Steller sea lions in the Gulf of Alaska. In: Environmental assessment of the Alaska Continental Shelf. Final reports of principal investigators. US Department of Commerce and US Department of Interior, OCSEAP, Anchorage, AK, Vol 19, p 445-546

Carbone C, Gittleman JL (2002) A common rule for the scaling of carnivore density. Science 295:2273-2276

Carlson HR (1980) Seasonal distribution and environment of Pacific herring near Auke Bay, Lynn Canal, Southeastern Alaska. Trans Am Fish Soc 109:71-78

Cline D (1982) Council grounds of the eagles. Alaska fish tales and game trails. (Winter):23-27

Corton A (2002) The role of 'conservatism' in herring migrations. Rev Fish Biol Fish 11:339-361

Cottrell PE, Trites AW (2002) Classifying prey hard part structures recovered from fecal remains of captive Steller sea lions (Eumetopias jubatus). Mar Mamm Sci 18:525-539

Croxall JP (1992) Southern ocean environmental changes: effects on seabird, seal, and whale populations. Phil Trans R Soc Lond B 338:319-328

da Silva J, Neilson JD (1985) Limitations of using otoliths recovered in scats to estimate prey consumption in seals. Can J Fish Aquat Sci 42:1439-1442

Davoren GK, Montevecchi WA, Anderson JT (2003) Search strategies of a pursuit-diving marine bird and the persistence of prey patches. Ecol Monogr 73:463-481

Engen S, Stenseth NC (1984) A general vision of optimal foraging theory: the effect of simultaneous encounters. Theor Popul Biol 26:192-204

Fiscus CH, Baines GA (1966) Food and feeding behavior of Steller and California sea lions. J Mammal 47:195-200

Fretwell SD (1972) Populations in a seasonal environment. Princeton University Press, Princeton, NJ

Frost BW, McCrone LE (1979) Vertical distribution, diet vertical migration, and abundance of some mesopelagic fishes in the eastern subarctic Pacific Ocean in summer. Fish Bull US 76:751-770

Groot C, Margolis L (eds) (1991) Pacific salmon life histories. University of British Columbia Press, Vancouver

Hart JL (1973) Pacific fishes of Canada. Bull Fish Res Board Can 180

Hjellvik V, Godø OR, Tjøstheim D (2004) Diurnal variation in acoustic densities: Why do we see less in the dark? Can J Fish Aquat Sci 61:2237-2254

Huse I, Korneliussen R (2000) Diel variation in acoustic density measurements of overwintering herring (Clupea harengus L.). ICES J Mar Sci 53:863-873

Iverson SJ, Frost KJ, Lang SLC (2002) Fat content and fatty acid composition of forage fish and invertebrates in Prince William Sound, Alaska: factors contributing to among and within species variability. Mar Ecol Prog Ser 241:161-181

Jönsson KI (1997) Capital and income breeding as alternative tactics of resource use in reproduction. Oikos 78:57-66

Lance MM, Orr AJ, Riemer DS, Weise MJ, Laake J (2001) Pinniped food habits and prey identification techniques protocol. AFSC Processed Rep 2001-04. Alaska Fish Sci Cent, Natl Mar Fish Serv, NOAA, Seattle, WA

Lea MA, Nichols PD, Wilson G (2002) Fatty acid composition 
of lipid-rich myctophids and makerel icefish (Champsocephalus gunnari)-Southern Ocean food-web implications. Polar Biol 25:843-854

LeBoeuf BJ, Crocker DE, Costa DP, Blackwell SB, Webb PM, Houser DS (2000) Foraging ecology of northern elephant seals. Ecol Monogr 70:353-382

Logerwell EA, Schaufler LE (2005) New data on proximate composition and energy density of Steller sea lion (Eumetopias jubatus) prey fills seasonal and geographic gaps in existing information. Aquat Mamm 31:62-82

MacLennan DN, Simmonds EJ (1992) Fisheries acoustics. Chapman \& Hall, New York

Marston BH, Willson MF, Gende SM (2002) Predator aggregations during eulachon Thaleichthys pacificus spawning runs. Mar Ecol Prog Ser 231:229-236

Merrick RL, Chumbley MK, Byrd GV (1997) Diet diversity of Steller sea lions (Eumetopias jubatus) and their population decline in Alaska: a potential relationship. Can J Zool 54:1342-1348

Milinski M (1994) Long-term memory for food patches and implications for ideal free distributions in sticklebacks. Ecology 75:1150-1156

Orians GH, Pearson NE (1977) On the theory of central place foraging. In: Horn DJ, Stairs GR, Mitchell RD (eds) Analysis of ecological systems. Ohio State University Press, Columbus, OH, p 153-177

Orr AJ, Harvey JT (2001) Quantifying errors associated with using fecal samples to determine the diet of California sea lion (Zalophus californianus). Can J Zool 79:1080-1087

Pitcher KW (1981) Prey of the Steller sea lion, Eumetopias jubatus, in the Gulf of Alaska. Fish Bull US 79:467-472

Pitcher KW, Calkins DG (1981) Reproductive biology of Steller sea lions in the Gulf of Alaska. J Mammal 62: 599-605

Pitcher KW, Burkanov VN, Calkins DG, Le Boeuf BJ, Mamaev EG, Merrick RL, Pendleton GW (2001) Spatial and temporal variation in the timing of births of Steller sea lions. J Mammal 82:1047-1053

Purcell J (1996) Mesopelagics. In: Pauly D, Christensen V, Haggan N (eds) Mass-balance models of northeastern Pacific ecosystems. Fisheries Center Research Report 4(1). University of British Columbia, Vancouver. Also available at: www.fisheries.ubc.ca/publications/reports/fcrr.php

Reichmuth Kastak CR, Schusterman RJ (2002) Long-term memory for concepts in a California sea lion (Zalophus californianus). Anim Cogn 5:225-232

Rickey MH (1994) Maturity, spawning, and seasonal movement of arrowtooth flounder, Atheresthes stomias, off Washington. Fish Bull US 93:127-138

Rounsefell GA (1930) Contribution to the biology of the Pacific herring, Clupea pallasii, and the condition of the fishery in Alaska. Bull US Bur Fish XLV:227-320

Sigler MF, Csepp DJ (in press) Seasonal abundance of two important forage species of Steller sea lions in the North Pacific Ocean, Pacific herring and walley pollock. Fish Res

Editorial responsibility: Howard Browman (Associate Editorin-Chief), Storebø, Norway
Sigler MF, Womble JN, Vollenweider JJ (2004) Availability to Steller sea lions (Eumetopias jubatus) of a seasonal prey resource: a pre-spawning aggregation of eulachon (Thaleichthys pacificus). Can J Fish Aquat Sci 61:1475-1484

Similä T, Holst JC, Christensen I (1996) Patterns in seasonal occurrence and diet of killer whales in northern Norway with reference to the distribution and abundance of Norwegian spring-spawning herring. Can J Fish Aquat Sci 53:769-779

Sinclair EH, Zeppelin TK (2002) Seasonal and spatial differences in diet in the western stock of Steller sea lions (Eumetopias jubatus). J Mammal 83(4):973-990

Smoker W, Pearcy WG (1970) Growth and reproduction of the lanternfish Stenobrachius leucopsaurus. J Fish Res Board Can 27:1265-1275

Soto KH, Trites AW, Arias-Schreiber M (2004) The effects of prey availability on pup mortality and the timing of birth of South American sea lions (Otaria flavescens) in Peru. J Zool (Lond) 264:419-428

Thedinga JT, Johnson SW, Csepp DJ (2006) Nearshore fish assemblages in the vicinity of two Steller sea lions haulout in southeastern Alaska. In: Trites AW, Atkinson SR, DeMaster DP, Fritz LW, Gelatt TS, Rea LD, Wynne KM (eds) Sea lions of the world. Alaska Sea Grant College Program, University of Alaska Fairbanks, AK

Thomas GL, Thorne RE (2001) Night-time predation by Steller sea lions. Nature 411:1013

Tollit DJ, Wong M, Winship AJ, Rosen DAS, Trites AW (2003) Quantifying errors associated with prey skeletal structures from fecal samples to determine the diet of Steller's sea lion (Eumetopias jubatus). Mar Mamm Sci 19:724-744

Tollit DJ, Heaslip SG, Zeppelin TK, Joy R, Call KA, Trites AW (2004) A method to improve size estimates of walleye pollock (Theragra chalcogramma) and Atka mackerel (Pleurogrammus monopterygius) consumed by pinnipeds: digestion correction factors applied to bones and otoliths recovered in scats. Fish Bull US 102:498-508

Trumble SJ, Castellini MA (2005) Diet mixing in aquatic carnivore, the harbour seal. Can J Zool 83:851-859

Vollenweider JJ (2005) Variability in Steller sea lion (Eumetopias jubatus) prey quality in southeastern Alaska. MS thesis, University of Alaska, Fairbanks, AK

Winship AJ, Trites AW, Rosen DAS (2002) A bioenergetic model for estimating the food requirements of Steller sea lions $\mathrm{Eu}$ metopias jubatus in Alaska. Mar Ecol Prog Ser 229:291-312

Womble JN (2003) Seasonal distribution of Steller sea lions (Eumetopias jubatus) in relation to high-quality ephemeral prey species in southeastern Alaska. MS thesis, University of Alaska, Fairbanks, AK

Womble JN, Willson MF, Sigler MF, Kelly BP, Van Blaricom GR (2005) Distribution of Steller sea lions (Eumetopias jubatus) in relation to spring-spawning fish in SE Alaska. Mar Ecol Prog Ser 294:271-284

Zar JH (1999) Biostatistical analysis, 4th edn. Prentice-Hall, Upper Saddle River, NJ

Submitted: September 12, 2005; Accepted: April 7, 2006

Proofs received from author(s): October 16, 2006 